\title{
PEMBUATAN NUGGET IKAN LELE (CLARIAS SP) DENGAN VARIASI PENAMBAHAN TEPUNG TERIGU
}

\author{
Making Of Lele Fish Nugget (Clarias sp) With Additional Variation Of Wheat Flour \\ Frangky Fransiskus Tumion ${ }^{1}$, Ningrum Dwi Hastuti ${ }^{2}$ \\ 1). Staf Pengajar Prodi Teknologi Hasil Perkebunan Politeknik Negeri Ketapang. \\ ${ }^{2)}$ Staf Pengajar di Politeknik Negeri Pontianak. \\ Email: Ningrum@gmail.com
}

\begin{abstract}
ABSTRAK
Nugget merupakan salah satu produk olahan daging beku yang memiliki daya simpan yang cukup lama. Penelitian ini dilakukan untuk mengetahui pengaruh variasi penambahan tepung terigu terhadap pembuatan nugget ikan lele yang dihasilkan dan untuk mengetahui tingkat kesukaan konsumen terhadap nugget dalam pembuatan nugget ikan lele. Metode yang digunakan dalam penelitian pembuatan nugget dari ikan lele ini antara lain menggunakan tiga variasi penambahan tepung terigu diantaranya dengan variasi penambahan tepung terigu sebanyak $5 \%, 10 \%, 15 \%$, selanjutnya dilakukan pengujian produk uji organoleptik dan analisa kandungan kadar protein dan kadar air pengujian tersebut dilakukan di Laboratorium Jurusan Teknologi Pertanian, Politeknik Negeri Ketapang. Hasil penelitian menunjukkan pengaruh variasi penambahan tepung terigu 5\%,10\%, 15\% dan penambahan ikan lele masing-masing sebanyak 500 gr pada kadar protein berturut - turut 15, 55\%, 14, 70\% dan 13,77\% dan kadar air berturut - turut 50,34\%, 48,58\% dan 42, $08 \%$ sedangkan uji organoleptik dengan atribut penilaian tekstur dan rasa, yang paling disukai yaitu penambahan tepung terigu $5 \%$ yang mempunyai skor rata -rata tekstur 5 rasa 5,44 sedangkan penilaian aroma tidak berbeda nyata.

Kata kunci: Tepung terigu, nugget, ikan lele.
\end{abstract}

\begin{abstract}
Nugget is one of the frozen meat processed products that have a long shelf life. This study was conducted to determine the effect of variations in the addition of wheat flour to the production of catfish nugget produced and to determine the level of consumer preference for nuggets in making catfish nuggets. The method used in the research of making catfish nuggets includes using three variations of wheat flour addition including variations in the addition of wheat flour as much as 5\%,10\%, 15\%, then testing the organoleptic test products and analyzing protein content and moisture content testing this was done at the Laboratory of Agricultural Technology, Ketapang State Polytechnic. The results showed the effect of variations in the addition of wheat flour $5 \%, 10 \%, 15 \%$ and the addition of catfish each as much as 500 grams of protein content in a row of 15, 55\%, 14, 70\% and $13.77 \%$ and successive water content $50.34 \%, 48.58 \%$ and $42.8 \%$ while organoleptic tests with attributes of texture and taste, the most preferred is the addition of 5\% wheat flour which has an average score of 5 flavors of texture 5.44 while aroma assessment not significantly different.
\end{abstract}

Keywords: Wheat flour, nuggets, catfish. 


\section{PENDAHULUAN}

Ikan Lele dumbo (Clarias sp)termasuk dalam jenis ikan air tawar dengan ciri - ciri tubuh yang memanjang, agak bulat, kepala gepeng, tidak memiliki sisik, mulut besar, warnakelabu sampai hitam. Kulit lele dumbo berlendir tidak bersisik, berwarna hitam pada bagian punggung (dorsal) dan bagiansamping (lateral) (Suyanto 2007). Potensi ikan lele di Ketapang sangat mudah di cari, karena ikan lele merupakan sumber mata pencarian masyarakat ketapang. Melimpahnya hasil panen lele sering membuat harga jual ikan lele rendah. Oleh karena itu untuk memanfaatkan ikan lele tersebut di perlukan inovasi baru sehingga menjadi suatu produk ikan lele yang memiliki nilai ekonomis tinggi dan daya simpan yang lama.

Nugget merupakan salahsatu bentuk produk makanan beku siap saji, yaitu produk yang telahmengalami pemanasan sampai setengah matang (precooked), kemudiandibekukan. Produk beku siap saji ini hanya memerlukanwaktu penggorengan selama 1 menit pada suhu $150^{\circ} \mathrm{C}$ ( Ginting, 2015 ). Nugget ikan lele merupakan olahan produk baru. Pembuatan nugget dari ikan lele memerlukan bahan-bahan tambahan yang berperan sebagai bahan pengisi dan bahan pengikat disamping bumbu dan rempahrempah, bahan pengisi yang biasa digunakan adalah tepung.

Syarbini (2013) menyatakan bahwa tepung terigu adalah hasil daripenggilingan biji gandum. Umumnya tepung terigu biasa digunakan untuk membuat aneka makanan seperti kue dan roti. Tepung terigumengandung gluten yang dapat membuat adonan makanan menjadi tipis danelastis.

Beberapa penelitian seperti yang dilakukan Surawan, (2007) pada pembuatan nugget ikan tuna dengan variasi penambahan tepung terhadap nilai uji organoleptik, dimana nugget dengan bahanbaku ikan masih belum banyak dijumpai di pasaran. Pengembangan ikan sebagai bahan baku nugget sangat penting, karena ikan mengandung protein yang tidak kalah tinggi dengan ayam terutama untuk membantu meningkatkan nilai ekonomis produk. Hal ini yang menjadi dasar dilakukkannya penelitian terhadap nugget.

\section{METODELOGI PENELITIAN}

\section{Tempat dan Waktu Penelitian}

Penelitian ini dilakukan di Laboratorium Jurusan Teknologi Pertanian Politeknik Negeri Ketapang selama dua bulan. 


\section{Alat dan Bahan Penelitian}

Alat-alat yang digunakan pada penelitian ini antara lain blender, baskom plastik, nampan, piring, sendok, Loyang, pisau, timbangan, cetakan, dandang pengukus, kompor, wajan dan freezer.

Alat yang digunakan untuk analisa kadar air dan protein adalah neraca analitik, oven, desikator, cawan petri, spatula, seperangkat alat destilasi, labu kjhedal, gelas ukur, labu ukur, erlenmyer, pipet gondok, pipet ukur, seperangkat alat titrasi, corong glass, beaker glass.

Bahan-bahan yang diperlukan dalam penelitian ini antara lain ikan lele, tepung terigu, garam, telur, merica, bawang putih, tepung panir, air dan minyak goreng. Bahan yang digunakan untuk analisa kadar air dan protein adalah sampel nugget ikan lele, katalis, $\mathrm{H}_{2} \mathrm{SO} 4, \mathrm{NaOH}$ $50 \%$, asam borak $2 \%$, indikator $\mathrm{PP}, \mathrm{NaOH}$ $0,1 \mathrm{~N}$ untuk titrasi.

\section{Presedur Kerja}

Ikan lele yang akan digunakan harus dibersihkan terlebih dahulu dengan air. Setelah dibersihkan, daging ikan lele dan tulangnya dipisahkan. Selanjutnya daging ikan lele dihancurkan dan dihaluskan menggunakan blender \pm 5 menit, setelah itu dimasukan tepung terigu dengan variasi 5\% tepung terigu : 500 gram ikan lele, $10 \%$ tepung terigu : 500 gram ikan lele, 15\% tepung terigu : 500 gram ikan lele. Setelah itu masukan bahan tambahan seperti garam $4,5 \mathrm{~g}$, merica $0,5 \mathrm{~g}$, bawang putih $2 \mathrm{~g}$, air $\pm 5 \mathrm{ml}$, aduk hingga merata menggunakan mixer. Selanjutnya adonan dimasukan kedalam cetakan dan dikukus kedalam dandang pengukus selama 30 menit. Setelah dikukus, didinginkan kedalam freezer dengan suhu $\pm 3^{\circ} \mathrm{C}$. Nugget yang telah di dinginkan kemudian di cetak dengan bentuk yang diinginkan, selanjutnya dianalisa kadar air, kadar protein dan uji organoleptik.

\section{Parameter Uji Laboratorium}

Parameter dalam penelitian ini meliputi analisa kadar air, kadar protein dan organoleptik metode hedonik untuk mengetahui kualitas dari produk nugget menurut penilaian panelis/konsumen. Analisa kadar air menggunakan metode oven sedangkan analisa protein menggunakan metode kjhedal.

\section{Analisa Kadar Air}

Analisa kadar air berfungsi untuk mengetahui kandungan air pada suatu produk. Prosedur analisa kadar air dimulai dengan menimbang wadah kosong dengan menggunakan neraca analitik (w) 
selanjutnya masukan sampel nugget sebanyak 2 grm pada wadah kosong dan timbang beratnya (w), setelah ditimbang masukan dalam oven selama 3 jam, kemudian masukan dalam desikator selama 15 menit, selanjutnya timbang sampel pada neraca analitik. Lakukan prosedur pengovenan, pendinginan dan penimbangan sampai didapat berat konstan 0,002 dari sample selama 1 jam. Kemudian hitung dengan rumus.

$$
\% \text { kadarair }=\frac{w 1-w 2}{w 1-w o} \times 100 \%
$$

\section{Analisa kadar protein}

Analisa kadar protein metode yang digunakan yaitu metode khjeldal dengan tiga tahap prosedur analisa yang pertama tahap destruksi yang di awali dengan penimbangan sampel sebanyak $1 \mathrm{~g}$, sampel dimasukan kedalam labu kjeldahl kemudian ditambah $\mathrm{H} 2 \mathrm{SO} 4$ sebanyak 20 $\mathrm{ml}$, selanjutnya ditambahkan katalisator, simpan tabung pada rak labu pemanas tutup dan kunci rapat, nyalakan alat scrubber dan digestion dengan menekan tombol power. Putar pemanas pada skala 10 selama 5 menit untuk pemanasan dan putar kembali pada skala 8 selama 3 jam. Akhir tahap ini diawali dengan perubahan warna sampel mejadi hijau muda jernih. Selanjutnya masuk pada tahap destilasi.
Ambil sampel yang sudah dingin pada rak destruksi masukan pada tabung destilasi tambahkan aquadest sebanyak 50 ml tambahkan 10 ml larutan $\mathrm{NaOH} 50 \%$ selanjutnya teteskan indikator phenolphtalein sebanyak 3 tetes, dipasang tabung destilasi pada alat destilasi. Siapkan erlenmeyer dan isi dengan asam borat $2 \%$ sebanyak $60 \mathrm{ml}$ letakan pada bagian bawah hasil destilasi. Nyalakan alat destilasi dan putar pada skala 2 tunggu hingga selesai. Selanjutnya titrasi menggunakan $\mathrm{NaOH} 0,1 \mathrm{~N}$ dan teteskan dengan indikator phenolphtalein sebanyak 3 tetes, hasil titrasi ditandai dengan perubahan warna menjadi ungu muda catat volume titrasinya dan hitung \% nitrogennya dengan rumus :

$N \%$
$=\frac{(\text { V.titrasiblanko }- \text { V.titrasisample }) \times N N a O H \times 14,008 \times 100}{\text { beratsampel } \times 1000}$ Kadar protein $(\%)=\% \quad \mathrm{~N} \times$ faktor konversi $(6,25)$.

\section{Uji organoleptik}

Cita rasa suatu bahan adalah respon ganda dari bau dan rasa. Bila digabungkan dengan perasaan (konsistensi dan tekstur) dari makanan di dalam mulut, konsumen dapat membedakan suatu makanan dengan jenis makanan lain. Cita rasa makanan ditimbulkan oleh terjadinya rangsangan terhadap indera pengecap dalam tubuh 
manusia. Makanan yang memiliki cita rasa tinggi adalah makanan yang disajikan dengan menarik menyebarkan bau yang sedap dan memberikan rasa yang lezat (Ammermen, 1987).

25 orang panelis diminta memberikan penilainya dengan skala amat sangat suka, sangat suka, suka, netral, tidak suka, sangat tidak suka, amat sangat tidak suka dengan atribut penilaian tekstur, rasa dan aroma terhadap 3 contoh produk yang disajikan. Masing-masing produk diberi kode yang berbeda-beda yaitu 467, 738, 672.

\section{HASIL DAN PEMBAHASAN}

\section{Kadar Air}

Kadar air merupakan banyaknya air yang terkandung dalam bahan yang dinyatakan dalam persen. Kadar air juga merupakan satu karakteristik yang sangat penting pada bahan pangan, karena air dapat mempengaruhi penampakan, tekstur, dan citarasa pada bahan pangan. Kadar air dalam bahan pangan ikut menentukan kesegaran dan daya awet bahan pangan tersebut (Sudarmadji, 2003).

Hasil analisa kadar air pada produk nugget ikan lele dapat di lihat pada tabel 4.1 sebagai berikut :
Tabel 4.1 Hasil Pengamatan Analisa Kadar Air Pada Nugget Ikan lele

\begin{tabular}{|c|l|c|}
\hline No & \multicolumn{1}{|c|}{ Perlakuan } & Kadar Air \\
\hline 1 & $\begin{array}{l}\text { Penambahan tepung } \\
\text { terigu 5\% }\end{array}$ & $50,34 \%$ \\
\hline 2 & $\begin{array}{l}\text { Penambahan tepung } \\
\text { terigu 10\% }\end{array}$ & $48,58 \%$ \\
\hline 3 & $\begin{array}{l}\text { Penambahan tepung } \\
\text { terigu 15\% }\end{array}$ & $42,08 \%$ \\
\hline
\end{tabular}

Hasil analisa kadar air produk nugget ikan lele dapat dilihat pada gambar grafik 4.1.

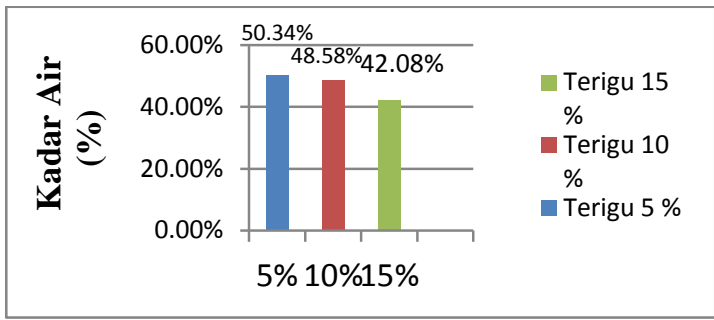

Gambar 4.1. Grafik Nilai Kadar Air Nugget Ikan Lele

Gambar grafik 4.1 menunjukan hasil nilai kadar air tertinggi terdapat pada nuggetikan lele dengan variasai penambahan tepung terigu $5 \%$ yaitu $50,34 \%$ sedangkan nilai kadar air terendah didapat dari variasi penambahan tepung terigu $15 \%$. Semakin banyak penambahan tepung terigu pada nugget maka semakin rendah kadar air yang dihasilkan. Hal ini disebabkan semakin banyak penambahan tepung maka semakin banyak air yang teperangkap di granula pati pada saat proses gelatinisasi 
sehingga air yang terdapat pada nugget tidak terukur pada saat dianalisa.

Moehyl (1992), menyatakan bahwa tepung juga digunakan untuk pengentalan makanan, kemampuan pengentalan tepung ini disebabkan oleh daya serapnya terhadap air sehingga butiran-butiran tepung tersebut membesar dan apabila dipanaskan maka granula tersebut akan rusak dan pecah sehingga terjadi proses gelatinisasi. Pada peristiwa gelatinisasi tepung, viskositas bahan akan meningkat karena air telah masuk kedalam butiran tepung dan tidak bisa bergerak bebas lagi.

\section{Kadar Protein}

Protein merupakan suatu zat makanan yang sangat penting bagi tubuh karena zat ini berfungsi sebagai sumber energi dalam tubuh serta sebagai zat pembangun dan pengatur. Pada umumnya kadar protein di dalam bahan pangan menentukan mutu bahan pangan itu sendiri, nilai gizi dari suatu bahan pangan ditentukan bukan saja oleh kadar nutrien yang dikandungnya, tetapi juga oleh dapat tidaknya nutrien tersebut digunakan oleh tubuh (Muchtadi, 1993).

Hasil analisa kadar protein pada produk nugget ikan lele dapat di lihat pada tabel 4.2. Dimana nilai tertinggi kadar protein pada produk nugget ikan lele yaitu dengan perlakuan penambahan tepung terigu $5 \%$ dengan nilai $15,55 \%$.

Tabel 4.2 Hasil Pengamatan Analisa Kadar protein Pada Nugget

Ikan lele

\begin{tabular}{|c|l|c|}
\hline No & \multicolumn{1}{|c|}{ Perlakuan } & $\begin{array}{c}\text { Kadar } \\
\text { Protein }\end{array}$ \\
\hline 1 & $\begin{array}{l}\text { Penambahan } \\
\text { tepung terigu 5\% }\end{array}$ & $15,55 \%$ \\
\hline 2 & $\begin{array}{l}\text { Penambahan } \\
\text { tepung terigu 10\% }\end{array}$ & $14,70 \%$ \\
\hline 3 & $\begin{array}{l}\text { Penambahan } \\
\text { tepung terigu 15\% }\end{array}$ & $13,77 \%$ \\
\hline
\end{tabular}

Hasil analisa kadar protein dengan perlakuan penambahan tepung terigu terhadap nugget ikan lele dapat dilihat pada gambar grafik 4.2 sebagai berikut:

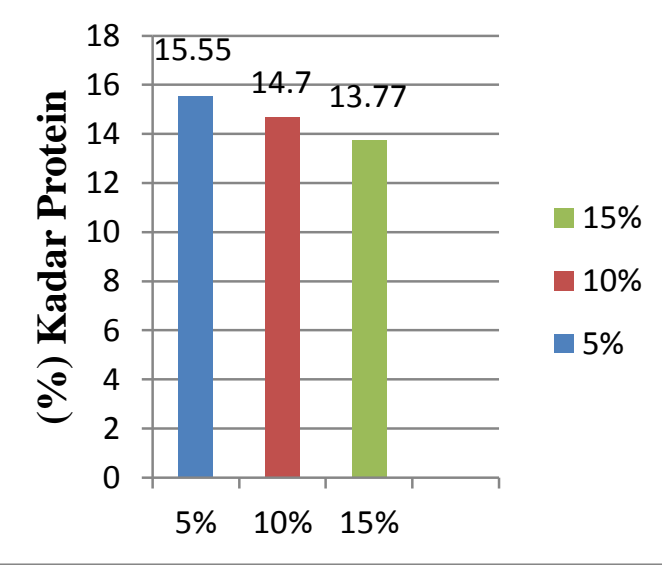

Gambar 4.2 Grafik Nilai Kadar Protein

Pada Nugget Ikan Lele

Berdasarkan hasil analisa kadar protein yang telah dilakukan diperoleh penurunan kadar protein yang terdapat pada ikan lele setelah dibuat menjadi nugget dimana berdasarkan sumber komposisi zat gizi lele disebutkan bahwa kadar protein lele sebelum diolah yaitu 
$17,7 \mathrm{mg}$ namun, setelah diolah menjadi nugget kadar protein ikan lele menjadi lebih rendah yaitu 13,77-15,55.

Nilai kadar protein tertinggi yaitu dengan penambahan tepung 5\%. Semakin sedikit penambahan tepung maka kadar protein semakin tinggi, hal ini sesuai dengan hasil analisa kadar air, dimana semakin sedikit penambahan tepung maka kadar air semakin tinggi. Menurut Fennema (1996) menyatakan bahwa protein yang terdapat dalam tepung terigu bersifat larut air, sehingga kadar air yang tinggi pada nugget dengan perlakuan penambahan tepung $5 \%$ mempengaruhi nilai kadar protein.

\section{Uji Organoleptik Tekstur}

Tekstur merupakan parameter yang sangat penting dalam menjaga mutu daging dan produk turunanya. Menurut (Hadiwiyoto, 2003), kesan kekenyalan pada nugget secara keseluruhan meliputi tekstur dan melibatkan bebarapa aspek diantaranya mudah atau tidaknya dikunyah menjadi potongan-potongan yang lebih kecil, dan jumlah residu yang tertinggal setelah dikunyah.

Hasil pengamatan tekstur pada produk nugget ikan lele dapat dilihat pada tabel 4.3 sebagai berikut:
Tabel 4.3 Nilai uji organoleptik tekstur pada nugget ikan lele

\begin{tabular}{|c|c|}
\hline Perlakuan & Rerata \\
\hline Penambahan tepung terigu 5\% & 5 \\
\hline Penambahan tepung terigu 10 \% & 4,64 \\
\hline Penambahan tepung terigu 15\% & 4,24 \\
\hline
\end{tabular}

Hasil uji kesukaan nugget ikan lele dengan parameter tekstur dapat di lihat pada Gambar grafik 4.3.

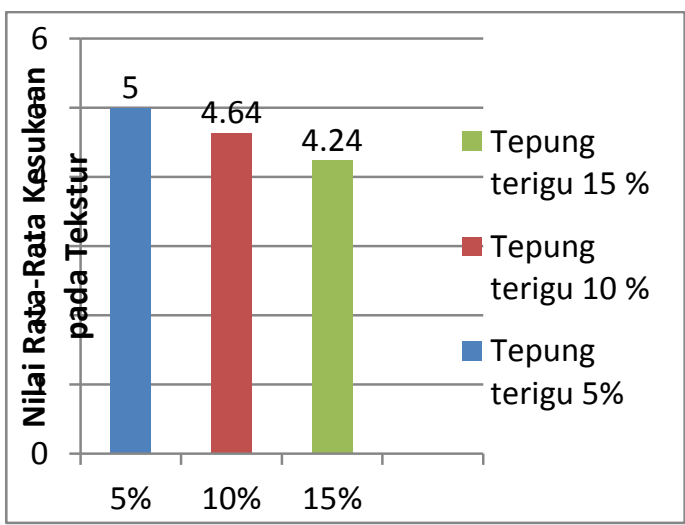

Gambar 4.3. Grafik Nilai Uji Kesukaan

Tekstur Pada Nugget Ikan Lele.

Gambar grafik 4.3 menunjukkan bahwa variasi penambahan tepung $5 \%$ berbeda nyata dengan variasi penambahan tepung $10 \%$ dan $15 \%$. Nilai rata - rata kesukaan panelis terhadap produk nugget ikan lele dengan parameter tekstur didapat hasil nilai organoleptik tertinggi terdapat pada penambahan tepung terigu 5\% sedangkan nilai organoleptik terendah pada parameter tekstur terdapat pada variasi penambahan tepung $15 \%$. Hal ini dikarenakan adanya proses gelatinisasi dimana terjadi pembengkakan granula pati yang menyebabkan perubahan struktur 
granula sehingga berpengaruh terhadap viskositas nugget lele sehingga nugget lele dengan penambahan tepung $15 \%$ lebih keras dibandingkan dengan $5 \%$.

Jumlah pati yang besar menyebabkan tekstur menjadi lebih padat dan cenderung keras Menurut Rospiati, (2007) tekstur akan berubah dengan berubahnya kandungan air. Jadi semakin banyak tepung terigu yang ditambahkan akan menyebabkan tekstur nugget lele semakin keras begitupun sebaliknya, semakin sedikit tepung yang ditambahkan maka tekstur nugget akan menjadi lembut sehingga penambahan tepung terigu $5 \%$ lebih disukai panelis karna memiliki tekstur yang tidak terlalu keras.

\section{Uji organoleptik rasa}

Rasa merupakan suatu zat atau komponen tertentu yang mempunyai beberapa fungsi dalam makanan, diantaranya dapat bersifat memperbaiki, membuat lebih bernilai atau dapat diterima sehingga peranan rasa disini mampu menarik kesukaan konsumen terhadap makanan tersebut. Rasa dinilai dengan indra perasa (lidah), yang merupakan kesatuan interaksi antara sifat sensoris aroma, rasa, dan tekstur merupakan keseluruhan rasa makanan yang dinilai Pengujian terhadap rasa dianggap penting karena dapat dengan cepat memberikan penilaian terhadap suatu produk yang diterima atau tidaknya (Winarno, 2004).

Hasil uji organoleptik terhadap rasa bertujuan untuk mengetahui tingkat kesukaan panelis pada tiap-tiap perlakuan. Hasil uji organoleptik terhadap rasa dapat dilihat pada tabel 4.4 sebagai berikut:

Tabel 4.4 Hasil pengamatan uji rasa pada produk nugget ikan lele.

\begin{tabular}{|l|c|}
\hline \multicolumn{1}{|c|}{ Perlakuan } & Rata-rata \\
\hline $\begin{array}{l}\text { Penambahan tepung } \\
\text { terigu 5\% }\end{array}$ & 5,44 \\
\hline $\begin{array}{l}\text { Penambahan tepung } \\
\text { terigu 10\% }\end{array}$ & 4,68 \\
\hline $\begin{array}{l}\text { Penambahan tepung } \\
\text { terigu 15\% }\end{array}$ & 4,4 \\
\hline
\end{tabular}

Hasil analisa uji organoleptik dengan parameter rasa dapat di lihat pada Gambar grafik 4.4. sebagai berikut :

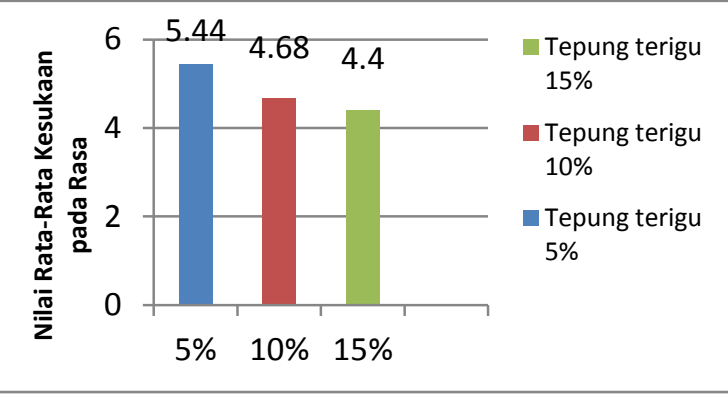

Gambar 4.4. Grafik Nilai Uji Kesukaan

Rasa Pada Nugget Ikan Lele

Gambar grafik 4.4 menunjukkan bahwa variasi penambahan tepung $5 \%$ berbeda nyata dengan variasi penambahan tepung $10 \%$ dan $15 \%$. Sedangkan penambahan tepung $10 \%$ dan $15 \%$ tidak 
berbeda nyata. Nilai uji kesukaan rasa tertinggi yaitu terdapat pada nugget ikan lele dengan variasi penambahan tepung terigu 5\% sedangkan nilai organoleptik terendah dengan parameter rasa terdapat pada penambahan tepung terigu $15 \%$. Adapun variasi tepung terigu 5\% lebih disukai yaitu karena penambahan tepung lebih sedikit sehingga rasa ikan yang dihasilkan lebih muncul dibandingkan dengan lebih banyak penambahan tepung terigu $10 \%$ dan $15 \%$.

\section{Uji Organoleptik Aroma}

Menurut kartika (2008), bau atau aroma dapat didefinsikan sebagai sesuatu yang dapat diamati dengan indera pembau, untuk dapat menghasilkan bau, zat-zat bau harus dapat menguap, sedikit dapat larut dalam air, dan sedikit dapat larut dalam lemak.

Hasil pengamatan uji organoleptik terhadap aroma nugget ikan lele dapat dilihat pada tabel 4.5 sebagai berikut:

Tabel 4.5 Hasil pengamatan aroma pada produk nugget ikan lele

\begin{tabular}{|l|c|}
\hline \multicolumn{1}{|c|}{ Perlakuan } & Rata-rata \\
\hline $\begin{array}{l}\text { Penambahan tepung } \\
\text { terigu 5\% }\end{array}$ & 5,12 \\
\hline $\begin{array}{l}\text { Penambahan tepung } \\
\text { terigu 10\% }\end{array}$ & 4,96 \\
\hline Penambahan tepung & 4,92 \\
\hline
\end{tabular}

terigu $15 \%$

Hasil analisa uji organoleptik dengan parameter aroma dapat di lihat pada Gambar grafik 4.5. sebagai berikut :

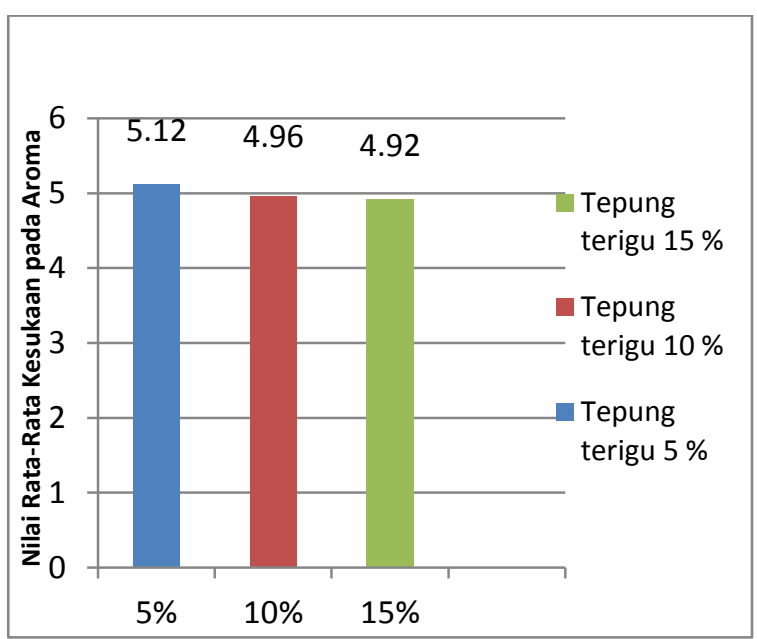

Gambar 4.5. Grafik Nilai Uji

Kesukaan Aroma Nugget Ikan Lele

Gambar grafik 4.5 menunjukkan nilai tingkat kesukaan aroma tertinggi yaitu terdapat pada nugget ikan lele dengan variasi penambahan tepung terigu 5\% sedangkan nilai organoleptik terendah dengan parameter aroma terdapat pada penambahan tepung terigu $15 \%$. Berdasarkan hasil uji kesukaan nugget lele dengan parameter aroma didapat hasil bahwa variasi penambahan tepung 5\%, $10 \%$ dan $15 \%$ tidak berbeda nyata.

Menurut Hadiwiyoto (2003) berbagai peptida-peptida dan asam amino bebas serta asam lemak bebas sering kali dikaitkan dengan rasa dan aroma daging ikan. Sebagian senyawa-senyawa tersebut 
bersifat volatil sehingga banyak berkurang karena menguap selama pengukusan. Hal inilah yang menyebabkan keberadaan senyawa-senyawa tersebut tidak lagi menimbulkan pengaruh yang signifikan ketika dilakukan pengujian.

\section{KESIMPULAN}

Hasil penelitian yang telah dilakukan terhadap nugget ikan lele dapat disimpulkan sebagai berikut :

1. Perlakuan kadar air dengan variasi penambahan tepung terigu $5 \% .10 \%$ dan $15 \%$ berturut-turut $50,34 \%$, $48,58 \%$ dan $42,08 \%$ sedangkan persentase kadar protein 15,55\%, $14,70 \%$, dan $13,77 \%$.

2. Berdasarkan uji organoleptik diketahui bahwa yang disukai oleh panelis yaitu dengan variasi penambahan tepung terigu $5 \%$ dengan skor tekstur 5, rasa 5,44, dan aroma 5,12.

\section{Saran}

Diharapkan perlu dilakukan penelitian lebih lanjut terhadap nugget ikan lele dengan variasi tepung yang lain maupun penambahan bahan-bahan lain untuk meningkatkan karakteristik mutu nugget ikan lele.

\section{DAFTAR PUSTAKA}

Andrianto, T. (2005). Pedoman Praktis Budidaya Ikan Lele. Yogyakarta.

Ammermen, G. R. (1987). Effect Of Equal Lethal HeatTreatmentat Various Times and Temperatures Selected Food. Purdue University Latayette. Indiana.

Artama, T, (2001). Pemanfaatan ikan tepung lemuru (Sardinella longicep )untuk meningkatkan mutu fisik dan nilai gizi crackers. Tesis . Program Pasca Sarjana. Institut Pertanian Bogor. Bogor.

Astawan, (2008). Sehat Dengan Hidangan Hewani. Penebar Swadaya. Jakarta.

Astawan, M. (1999). Membuat Mie Dan Bihun. Edisi Pertama. Penebar Swadaya. Jakarta.

Badan Standardisasi Nasional. (2002). Nugget Ayam. SNI 01-6683. Badan Standardisasi Nasional, Jakarta.

Buckle, K.A., Edwards, R.A., Fleet, G.H., dan Wootton, M. (1987). Ilmu Pangan. Universitas Indonesia. Jakarta

Elingosa, T. (1994). Pembuatan Fish Nugget dari Ikan Tenggiri. Skripsi. Jurusan Teknologi Pangan dan Gizi. Fakultas Teknologi Pertanian, IPB. Bogor.

Fennema, O. R. (1996). Food Chemistry, third edition. Marcel Dekker, Inc. New York.

Ginting. (2015). Penggunaan Bahan Pengisi Pada Nugget. Jurnal Agribisnis. Sumatera Utara. 
Ginting. (2005). Nugget ayam, bukan sampah. Hyperlink reference. 27 April 2015.

Hadiwiyoto, S. (2003). Hasil-hasil Olahan Susu, Ikan, Daging dan Telur. Liberty.Yogyakarta.

Kartika, B., Hastuti, P dan Supartono W., (2008). Pedoman Uji Inderawi Bahan Pangan, Pusat Antar Universitas Pangan dan Gizi UGM, Yogyakarta.

Kent, N., (1975). Technology of Cereals, Pergamon Press Oxford, New York.

Matz, S.A. (1992). Bakery Technology and Engineering. Third Edition. VanNostrand Reinhold. AVI. New York.

Matz. (1978). Cookies and Creackers Technology. 2rd ed. The AV1 Pub. Co. Inc. Westport. Conecticut.

Muchtadi,d. (1993). Evaluasi Nilai Gizi Pangan. Pangan dan Gizi, IPB, Bogor.

Moehyl, S., (1992). Seputar Tepung Terigu. UI-Press, Jakarta.

Purnomo, H. (1996). Dasar - dasar Pengolahan dan Pengawetan Daging. PT Grasindo, Jakarta

Ratnaningsih, (1999). Pembuatan Nugget Sebagai Pemanfaatan Daging Merah Tuna (thunnus obesus). Skripsi. Jurusan Teknologi Hasil Perikanan, Fakultas Teknologi Hasil Perikanan Dan Ilmu Kelautan, IPB, Bogor.

Rismunandar. (1987). Lada, Budidaya dan TataNiaganya. Penebar Swadaya. Jakarta.
Rismunandar. (1986). Membudidayakan Lima Jenis Bawang. Penerbit Sinar Baru.Bandung.

Rospiati, E. (2006). Evaluasi Mutu dan Nilai Gizi Nugget Daging Merah Ikan Tuna.Bogor

Subarna. (1992). Baking Technology. Pelatihan Singkat Prinsip-Prinsip Teknologi Pangan Bagi Food Inspector. Pusat Antar Universitas Pangan dan Gizi. IPB. Bogor.

Sudarmadji, S., Bambang Haryono dan Suhardi. (2003). Analisa Bahan Makanan dan Pertanian. Librty. Yogyakarta.

Surawan. (2007). Penggunaan Tepung Terigu, Tepung Beras, Tepung Tapioka dan Tepung Maizena terhadap Tekstur dan Sifat Sensoris Fish Nugget Ikan Tuna. Jurnal Sain Peternakan Indonesia. Bengkulu.

Suyanto, S.R., . (2007). Budidaya ikan lele. Penebar Swadaya. Jakarta.

Syarbini. (2013). Referensi Komplit Bahan, Proses Pembuatan Roti, dan Panduan Menjadi Bakery. Solo

Widianto, B., Ch. Retnaningsih, Sumardi, Soedarini, Lindayani, A. R. Pratiwi dan Lestari. (2002). Tips Pangan Teknologi, Nutrisi dan Keamanan Pangan. PT Grasindo. Jakarta.

Winarno, F. G. (2004). Analisa Pangan dan Gizi. PT Gramedia Pustaka Utama. Jakarta 